\title{
Factors Affecting the Performances of Internet Banking: A Case of Vietnam Commercial Banks
}

\author{
Binh Anh Huynh ${ }^{1}$, Nhan Hoang $\mathrm{Vo}^{2}$ \& Cuong Hung Pham ${ }^{3}$ \\ ${ }^{1}$ Ho Chi Minh City Center of Career, Vietnam \\ ${ }^{2}$ University of Medicine Pham Ngoc Thach, Vietnam \\ ${ }^{3}$ Foreign Trade University, Ho Chi Minh City Campus, Vietnam \\ Correspondence: Nhan Hoang Vo, University of Medicine Pham Ngoc Thach, \#86/2 Thanh Thai, District 10, Ho Chi \\ Minh City, Vietnam.
}

Received: April 9, 2016

Accepted: May 4, 2016

Online Published: May 13, 2016

doi:10.5430/ijfr.v7n3p13

URL: http://dx.doi.org/10.5430/ijfr.v7n3p13

\begin{abstract}
The study of factors affecting the performances of internet banking: a case of Vietnam commercial banks conducted during the period from July 2013 to October 2015. Regression results show that all three independent variables Quality of Network, Convenience of Customers and Security affect Performance by Sig coefficients of all two variables are less than 5\%. Factor "Quality of Network" is the most influential factor to Performance with Beta coefficient $=0.345$. Factor "Convenience" has beta coefficient $=0.302$ positive impact to Performance. And factor "Security" has beta coefficient $=0.151$ positive impact to Performance. Thus, the results demonstrate "Quality of Network" and "Convenience and Security" are all crucial focus factors impact to Performance.
\end{abstract}

Keywords: factors, performances, internet banking, commercial banks, Vietnam

\section{Introduction}

Internet banking (IB) is becoming a main trend in the financial markets today. In Vietnam, IB services are still new and have not received the attention of customers. When referring to the banking system, we often think of immediately to a system of bar work, building the buildings. Working hours of banks are restricted from 7-8 AM and 4-5 PM (Brick and mortar banking). But for the customer, busy with work and always short of time, they can not be satisfied with a system so rigid. Today, the development of science and technology, of new technologies like Internet, mobile networks, Web TV... has promoted the emergence of a new model of banking - electronic banking (clicks and mortar banking). By taking steps boom in recent years, electronic banking has been self-affirmed its essential role for the banking system. Since the first bank to offer banking services over the network first launched, until now, has a lot of curiosity, experimentation, success and failure on the road to building a banking system e-perfect, the best service to customers, and it has affirmed its inevitable tendency of the banking system in 21 st century is the development of e-banking system. In this era of explosion of Internet services today, financial institutions, banks in Vietnam increasingly diverse supplier of products and online services to their many customers over the Internet. However, besides the benefits that the online service offers, other financial institutions have a headache to find a solution to limit the adverse effects, impact on internet banking activities. It is considered as the legitimate interests of customers and also can not disregard the responsibility of providers of financial services the bank. Until now, most banks have online services and they also identified the factors affecting that activity, they have set out the policy measures to limit these weaknesses and promote the strengths to develop Internet banking system, boosting the bank's activities.

\section{Literature Review}

Commercial banks as a financial institution typical intermediate, plays an important role in adjust capital flow and meet investment needs of entities in the economy, simultaneous it also keeps important role in ensuring the economy operate smoothly, efficiently. Thus competition in the commercial bank is also the rivalry, scrambling customers based on all possibility of banks to meet the demand of customers about providing products and services has high quality. Creating their own characteristics compared with other commercial banks in the domestic market; create an advantage competition, increase bank profits, creating prestige, and brand position in the domestic market. 
Return on Asset (ROA). ROA is also another major ratio that indicates the profitability of a bank. It is a ratio of Income to its total asset. It measures the ability of the bank management to generate income by utilizing company assets at their disposal. In other words, it shows how efficiently the resources of the company are used to generate the income. It further indicates the efficiency of the management of a company in generating net income from all the resources of the institution. A higher ROA shows that the company is more efficient in using its resources.

Return on Equity (ROE). ROE is a financial ratio that refers to how much profit a company earned compared to the total amount of shareholder equity invested or found on the balance sheet. ROE is what the shareholders look in return for their investment. A business that has a high return on equity is more likely to be one that is capable of generating cash internally. Thus, the higher the ROE the better the company is in terms of profit generation. ROE is the ratio of Net Income after Taxes divided by Total Equity Capital. It represents the rate of return earned on the funds invested in the bank by its stockholders. ROE reflects how effectively a bank management is using shareholders' funds. Thus, it can be deduced from the above statement that the better the ROE the more effective the management in utilizing the shareholders capital.

Net Interest Margin (NIM). Net Interest Margin (NIM) is a measure of the difference between the interest income generated by banks and the amount of interest paid out to their lenders (for example, deposits), relative to the amount of their assets. It is usually expressed as a percentage of what the financial institution earns on loans in a specific time period and other assets minus the interest paid on borrowed funds divided by the average amount of the assets on which it earned income in that time period (the average earning assets). The NIM variable is defined as the net interest income divided by total earnings assets.

Earnings per share (EPS). Earnings per share (EPS) are generally considered to be the single most important variable in determining a share's price. It is also a major omponent used to calculate the price-to-earnings valuation ratio.

Price-Earnings Ratio (PE). A valuation ratio of a company's current share price compared to its per-share earnings. In general, a high $\mathrm{P} / \mathrm{E}$ suggests that investors are expecting higher earnings growth in the future compared to companies with a lower P/E. However, the P/E ratio doesn't tell us the whole story by itself. It's usually more useful to compare the $\mathrm{P} / \mathrm{E}$ ratios of one company to other companies in the same industry, to the market in general or against the company's own historical $\mathrm{P} / \mathrm{E}$. It would not be useful for investors using the $\mathrm{P} / \mathrm{E}$ ratio as a basis for their investment to compare the $\mathrm{P} / \mathrm{E}$ of a technology company (high $\mathrm{P} / \mathrm{E}$ ) to a utility company (low $\mathrm{P} / \mathrm{E}$ ) as each industry has much different growth prospects.

Nonperforming Loan (NPL). A sum of borrowed money upon which the debtor has not made his or her scheduled payments for at least 90 days. A nonperforming loan is either in default or close to being in default. Once a loan is nonperforming, the odds that it will be repaid in full are considered to be substantially lower. If the debtor starts making payments again on a nonperforming loan, it becomes a performing loan again, even if the debtor has not caught up on all the missed payments.

Enterprise Value (EV). A measure of a company's value, often used as an alternative to straightforward market capitalization. Enterprise value is calculated as market cap plus debt, minority interest and preferred shares, minus total cash and cash equivalents.

Internet banking. Many organizations today have responded to the competitive business environment by implementing e-business as part of their business strategies. With the growth of the internet, it is inevitable for banks to move towards providing online banking for their customers. Although the current branch based retail banking remains the most common method for conducting banking transactions, internet technologies has changed the way personal financial services are designed and delivered to customers (Wang et al., 2003). Shih and Fang (2004) describe internet banking as a new type of information system that uses the innovative resources of the internet and WWW (World Wide Web) to enable customers to effect financial activities in virtual space. For example, it allows customers to perform a wide range of banking transactions electronically via the bank's web site (Tan and Teo, 2000). Internet banking works the same way as the traditional banking services. The main difference is that customers are accessing their account and information, making payments and reconciling statements by using their computer rather than paper to complete the transactions. Internet banking services are crucial elements for the long-term survival of banks in the world of electronic commerce (Tan and Teo, 2000). The market for internet banking is forecasted to grow sharply in the next few years, affecting the competitive advantage enjoyed by traditional banks with physical branches (Duclaux, 1996; Liao et al., 1999). Although online banking is common in many developed countries, for many developing countries, online banking is still very much at its infancy. This is especially true for countries, such as Vietnam, which are still building up their IT infrastructure. One of the Vietnamese's government economic plans is to shift its focuses from agricultural production to the service industry. As banking is an important part of the service industry, it is important 
for the banks to operate efficiently through the use of online banking. Although online banking is still unfamiliar to many Vietnamese users and is still at an early stage of development, but with an internet population of 15 million users, there is a huge market potential for banks to explore (VietnamNet, 2009). However, for any technologies to be successfully introduced and used, the users have to accept and adopt the technology. Although online banking adoption studies have been conducted in many developed and Western countries, studies for a developing and fast growing country such as Vietnam remain very few. Therefore this study attempts to investigate the factors that can influence users' acceptance of online banking in Vietnam.

The adoption from D\&M IS Success model has exceeded all estimation. According to a citation search in the summer of 2002, more than 280 refereed papers in journals and proceedings that have referenced the D\&M Model during the period 1993 to middle of 2002 (Delone \& McLean, 2003). This number shows that the model is successful and can be adopted for other researches.

Follow the D\&M IS Success Model (1992), we develop the framework as following:

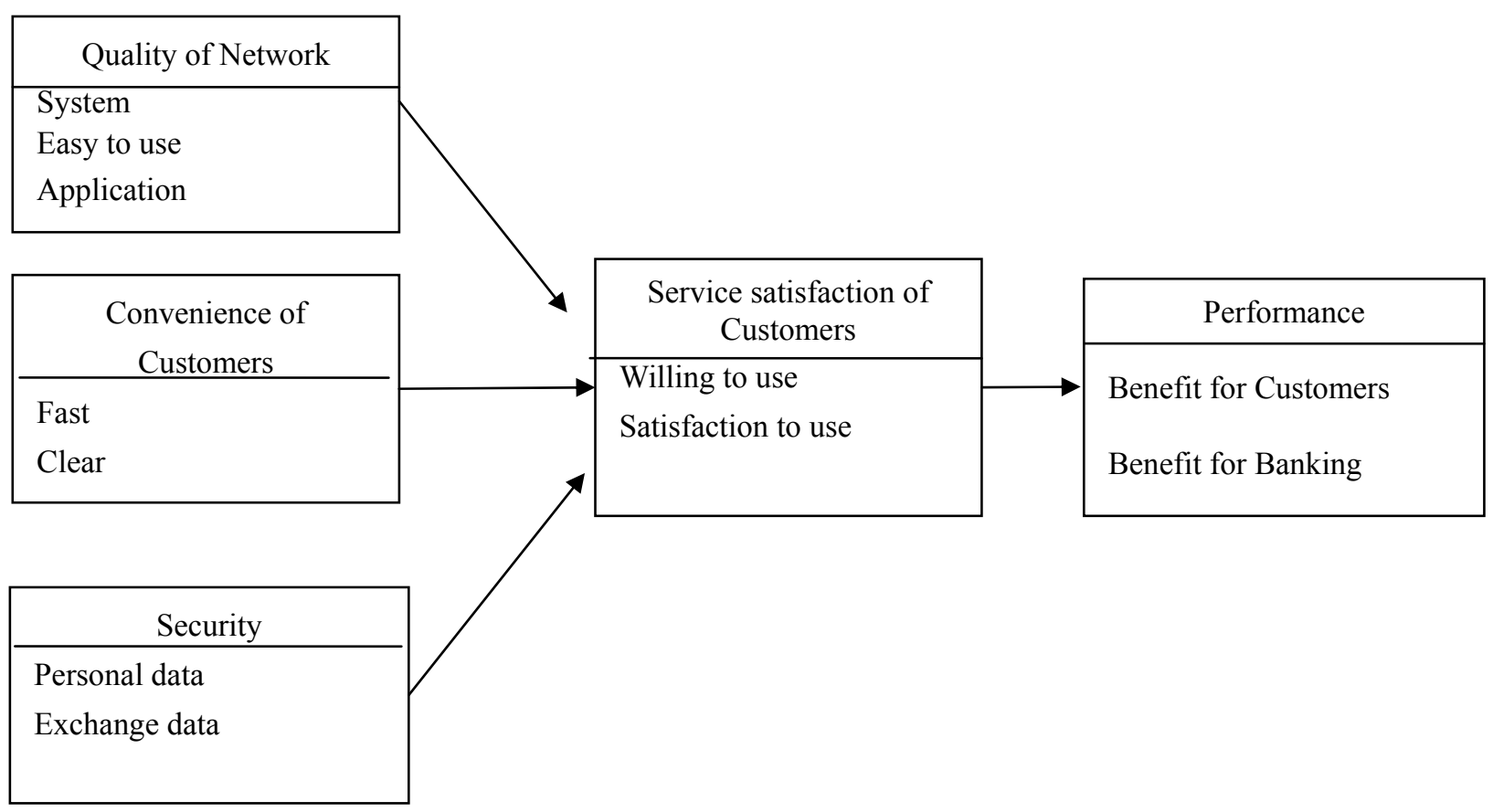

Figure 1. Research model for the factors affecting the performance of internet banking at commercial banks

\section{Hypothesis of the Study}

Hypothesis 1: The Quality of Network will direct impact on satisfaction of customers of Internet Banking in Vietnam.

Hypothesis 2: Convenience of Customers will direct impact on satisfaction of customers of Internet Banking in Vietnam.

Hypothesis 3: The security will direct impact on satisfaction of costumers of Internet Banking in Vietnam.

Hypothesis 4: The satisfaction of costumers will direct influence on the performance of Internet Banking in Vietnam.

\section{Research Methods}

Sample size should reach the reliability and value for purposes of a stretch for results from a population sample of the population being studied. Formula to estimate sample size for factor analysis to discover, according to Hair \& CTG researchers in 1998 noted that a minimum of 5 samples be used to measure a variable. In this study model has 18 variable observers, the sample size should be at least $130(=18 \times 5+50)$ customers. According to Tabachnick \& Fidell (1996), the regression analysis, the sample size was determined by the formula: $\mathrm{n}>=50+8 * \mathrm{~m}$ ( $\mathrm{n}$ is the sample size, $\mathrm{m}$ is the number of observed variables). This topic has 18 variables in the model study, so the minimum sample size is $194(=50+8 \times 18)$ customers. Thus, to conform to the standards above sample size, this study would 
expect the sample from 194 customers or more. In the Vietnam, there were more 1.000 .000 customers related to the Internet banking of commercial banks. I had surveyed 410 customers. After data are collected, reliable scale tested with Cranach's alpha index, and EFA (Exploratory Factor Analysis), which draws from the official scale. Based on analyzed results, the author offers Research processing for the performances of the Internet banking of commercial banks following.

\section{Research Results}

5.1 Descriptive Statistics for the Performances of Internet Banking

Table 1. Descriptive statistics for the performances of internet banking

\begin{tabular}{cccccc}
\hline Code & $\mathrm{N}$ & Minimum & Maximum & Mean & Std. Deviation \\
\hline Network1 & 385 & 1.00 & 5.00 & 4.2026 & .87231 \\
Network2 & 385 & 1.00 & 5.00 & 4.3455 & .76895 \\
Network3 & 385 & 1.00 & 5.00 & 4.2078 & .82818 \\
Network4 & 385 & 1.00 & 5.00 & 4.2519 & .85172 \\
Convenience1 & 385 & 1.00 & 5.00 & 4.4857 & .81358 \\
Convenience2 & 385 & 1.00 & 5.00 & 4.3870 & .72768 \\
Convenience3 & 385 & 1.00 & 5.00 & 4.4727 & .78721 \\
Convenience4 & 385 & 1.00 & 5.00 & 4.5299 & .75675 \\
Convenience5 & 385 & 1.00 & 5.00 & 4.4571 & .82844 \\
Security1 & 385 & 1.00 & 5.00 & 4.5039 & .71488 \\
Security2 & 385 & 1.00 & 5.00 & 4.5117 & .70747 \\
Security3 & 385 & 1.00 & 5.00 & 4.5117 & .68122 \\
Security4 & 385 & 1.00 & 5.00 & 4.4909 & .71118 \\
Security5 & 385 & 1.00 & 5.00 & 4.5065 & .71486 \\
\hline
\end{tabular}

Source: The researcher's collecting data and SPSS

Table 1 showed that there were 410 customers interviewed but 385 customers processed. The results showed that max value is 5 , minimum is 1 , mean is around 4.0 and Std. Deviation is around 1.0.

We had the result of descriptive statistics on Gender, Age, and Experience in Internet Banking, Using online service, Salary and Marriage status of customers.

Table 2. Descriptive Statistics for the demography

\begin{tabular}{llcc}
\hline & & Frequency & Percentage \\
\hline Gender & Male & 251 & 65.19 \\
\hline \multirow{2}{*}{ Age } & Female & 134 & 34.81 \\
\hline & Total & $\mathbf{3 8 5}$ & $\mathbf{1 0 0}$ \\
\hline & $18-20$ years old & 5 & 1.30 \\
\hline & $21-23$ years old & 36 & 9.35 \\
\hline \multirow{2}{*}{ Experience in Internet Banking } & Un-26 years old & 71 & 18.44 \\
\hline & Over 26 years old & 273 & 70.91 \\
\hline & Total & $\mathbf{3 8 5}$ & $\mathbf{1 0 0 . 0 0}$ \\
\hline & 1-3 years & 239 & 62.08 \\
\hline & 3-6 years & 76 & 19.74 \\
\hline
\end{tabular}




\begin{tabular}{llcc}
\hline & Over 6 years & 15 & 3.90 \\
\hline Using online service & Total & $\mathbf{3 8 5}$ & $\mathbf{1 0 0 . 0 0}$ \\
\hline & No & 168 & 43.64 \\
\hline Yes & Total & 217 & 56.36 \\
\hline & Less than 1 million VND & $\mathbf{3 8 5}$ & $\mathbf{1 0 0 . 0 0}$ \\
\hline & $1-2$ million VND & 2 & 0.52 \\
\hline & 3-5 million VND & 74 & 19.22 \\
\hline & $6-10$ million VND & 174 & 45.19 \\
\hline Marriage status & More than 10 million VND & 111 & 28.83 \\
\hline & Total & 24 & 6.23 \\
\hline & Married & $\mathbf{3 8 5}$ & $\mathbf{1 0 0 . 0 0}$ \\
\hline & Single & 257 & 66.75 \\
\hline
\end{tabular}

Source: The researcher's collecting data and SPSS

The above results of the Table 2 revealed that the result of the descriptive statistics from the demography following: Table 2 showed a total of 385, 251 males make up $65.19 \%$. For customer interviewed, the age accounted for the largest percentage is over 26 years old (accounting for $70.1 \%$ ), followed by 24 to 26 years old (accounting for 18.44\%), from 21 to 23 years old $(9.35 \%)$ and finally from 18 to 20 years old $(1.30 \%)$. The majority of customers interviewed have internet banking experience are under 1 year (including customers who have not used, accounting for $62.08 \%$ ), customers in internet banking experience from 1 to 3 years up 19.74\%, from 3 to 6 years accounted for 14, 29\% and over 6 years up only $3.90 \%$. In addition, only $56.36 \%$ of customers have used online service. Income, most clients have income from 3 to 5 million per month (accounting for $45.19 \%$ ), followed by income from 6 to 10 million per month (up $28.83 \%$ ), from 1 to 2 million up $19.22 \%$, over 10 million accounts for $6.23 \%$ and less than 1 million accounted for $0.52 \%$. And marriage status, most customers are married $(66.75 \%)$, the remains are single $(33.25 \%)$.

Cronbach's Alpha is a statistical test used to examine the correlation between variables. This involves two aspects are the relationship between the variables themselves and correlation of the scores of each variable with a score of all the variables of each respond. This method allows the analyzer remove the unsuitable variables and spam variables in the model. Accordingly, only those variables with Corrected Item-Total Correlation are greater than 0.3 and Cronbach's Alpha greater than 0.6 is accepted and appropriate to include the next step.

Table 3. Evaluate the reliability of the scale of the performances of internet banking

\begin{tabular}{cc}
\hline & $\begin{array}{c}\text { Corrected Item-Total } \\
\text { Correlation }\end{array}$ \\
\hline Quality of Network (Cronbach's Alpha = 0.800) & 0.760 \\
\hline Network1 & 0.518 \\
\hline Network2 & 0.765 \\
\hline Network3 & 0.436 \\
\hline Network4 & 0.668 \\
\hline Convenience of Customers (Cronbach's Alpha =0.813) & 0.618 \\
\hline Convenience1 & 0.616 \\
\hline Convenience2 & 0.626 \\
\hline Convenience3 & 0.490 \\
\hline Convenience4 & \\
\hline Convenience5 & \\
\hline
\end{tabular}




\begin{tabular}{cc}
\hline Security (Cronbach's Alpha = 0.989) & \\
\hline Security1 & 0.992 \\
\hline Security2 & 0.946 \\
\hline Security3 & 0.966 \\
\hline Security4 & 0.966 \\
\hline Security5 & 0.969 \\
\hline Service satisfaction of Costumers (Cronbach's Alpha = 0.792) & 0.655 \\
\hline Service1 & 0.655 \\
\hline Service2 & 0.709 \\
\hline Performance (Cronbach's Alpha $=0.829)$ & 0.709 \\
\hline Performance1 & \\
\hline Performance2 & \\
\hline
\end{tabular}

Source: The researcher's collecting data and SPSS

Table 3 showed that the detail of assessing the credibility of the scale. Results after checking the reliability of all factors, there is no factor or variable were excluded. All 14 independent variables and 4 dependent variables remaining are reliable and used for the next step. Besides, the above results of the table 4 revealed that all of components are very good for this research. Continue author analyzed the EFA to assess more accurately the scale, helping the uniform scale in research. Thus, based on the authors EFA analysis will evaluate the homogeneity of the observed variables and can be classified because of specific variables.

Table 4. Exploratory factor analysis results of the independent variables EFA

KMO and Bartlett's Test

\begin{tabular}{llc}
\hline Kaiser-Meyer-Olkin Measure of Sampling Adequacy. & 0.899 \\
Bartlett's Test of Sphericity & Approx. Chi-Square & 5967.883 \\
& df & 91 \\
& Sig. & 0.000 \\
\hline
\end{tabular}

Total Variance Explained

\begin{tabular}{|c|c|c|c|c|c|c|c|c|c|}
\hline \multirow[t]{3}{*}{ Com. } & \multicolumn{9}{|c|}{ Extraction Sums of Squared } \\
\hline & \multicolumn{3}{|c|}{ Initial Eigenvalues } & \multicolumn{3}{|c|}{ Loadings } & \multicolumn{3}{|c|}{ Rotation Sums of Squared Loadings } \\
\hline & Total & $\begin{array}{c}\% \text { of } \\
\text { Variance }\end{array}$ & $\begin{array}{c}\text { Cumulative } \\
\%\end{array}$ & Total & $\begin{array}{c}\% \text { of } \\
\text { Variance }\end{array}$ & $\begin{array}{c}\text { Cumulative } \\
\%\end{array}$ & Total & $\begin{array}{c}\% \text { of } \\
\text { Variance }\end{array}$ & Cumulative \% \\
\hline 1 & 6.937 & 49.548 & 49.548 & 6.937 & 49.548 & 49.548 & 4.658 & 33.269 & 33.269 \\
\hline 2 & 1.867 & 13.335 & 62.883 & 1.867 & 13.335 & 62.883 & 3.029 & 21.638 & 54.907 \\
\hline 3 & 1.477 & 10.547 & 73.430 & 1.477 & 10.547 & 73.430 & 2.593 & 18.523 & 73.430 \\
\hline 4 & .772 & 5.516 & 78.946 & & & & & & \\
\hline 5 & .715 & 5.107 & 84.053 & & & & & & \\
\hline 6 & .612 & 4.372 & 88.425 & & & & & & \\
\hline 7 & .496 & 3.545 & 91.970 & & & & & & \\
\hline 8 & .433 & 3.093 & 95.063 & & & & & & \\
\hline 9 & .383 & 2.735 & 97.798 & & & & & & \\
\hline 10 & .113 & .811 & 98.609 & & & & & & \\
\hline 11 & .083 & .594 & 99.202 & & & & & & \\
\hline 12 & .051 & .366 & 99.568 & & & & & & \\
\hline 13 & .049 & .352 & 99.920 & & & & & & \\
\hline 14 & .011 & .080 & 100.000 & & & & & & \\
\hline
\end{tabular}

Extraction Method: Principal Component Analysis.

Source: The researcher's collecting data and SPSS 
Table 4 showed that the variables after being tested by Cronbach's alpha and correlation will continue to check our correlation processing group. Exploratory Factor Analysis is used when Kaiser-Meyer-Olkin (KMO) greater than 0.5. The factor loading is less than 0.5 will continue to be excluded from the group variables to ensure convergence between the variables in a factor; stops when Initial Eigenvalue greater than 1 and the total variance larger than 0.5. In this study, Principal Component method with Varimax rotation will be used for Exploratory Factor Analysis.

Table 4 showed that KMO and Bartlett's inspection showed that the KMO coefficient 0.899 proved methods of factor analysis is appropriate authors, and Sig $=0.000$, suggesting that these variables are correlated with each other. Total variance extracted factors used to explain to be $73.430 \%$ the greater than $50 \%$ satisfactory conditions should factor analysis.

Results analyzed factors affecting the performances of internet banking into 3 extracted factors and the observed variables as follows:

Table 5. Rotated component matrix results of the independent variables EFA

\begin{tabular}{cccc}
\hline Code & \multicolumn{3}{c}{ Component } \\
\cline { 2 - 4 } & 1 & 2 & 3 \\
\hline Security1 & .939 & & \\
Security4 & .926 & & \\
Security3 & .925 & & \\
Security2 & .925 & & \\
Security5 & .925 & & \\
Convenience2 & & .780 & \\
Convenience1 & & .743 & .883 \\
Convenience3 & & .729 & .648 \\
Convenience4 & & .683 & \\
Convenience5 & & & \\
Network3 & & & \\
Network1 & & & \\
Network4 & & & \\
Network2 & & & \\
\hline
\end{tabular}

Source: The researcher's collecting data and SPSS

Table 5 showed that the first factor (factor X1) includes as follows variables: Security1: Customer's personal information is secure; Security2: Site transactions through Internet Banking system no one can reach while performing transactions; Security3: Never lost money in my account; Security4: Control transaction in the account; Security5: Always successful transaction. All variables have factor loading is above 0.5 so they are included in the research model. Five variables entered into a factor with relatively high factors loading. This is a group of variables about Security of Internet Banking. These variables are merged into one factor "Security".

The second factor (factor X2) includes as follows variables: Convenience1: Do not take more time for an Internet banking transaction; Convenience2: Get help as soon as the bank's customer requirements; Convenience3: Transaction done quickly after receiving orders' customers; Convenience4: No crashes or system error after receiving orders; Convenience5: The customers can easily find the item in a transaction that should be performed. All variables have factor loading is above 0.5 so they are included in the research model. Five variables enter into a factor with relatively high factor loading. This is a group of variables about convenience of customers. These variables are merged into one factor, "Convenience".

The third factor (factor X3) includes as follows variables: Network1: Internet banking system had developed in Viet Nam; Network2: The customers easily to use Internet Banking product; Network3: Strictly about the payment and internet banking products; Network4: There were errors in individual transactions (such as lack of cash withdrawal, transfer errors). All variables have factor loading is above 0.5 so they are included in the research model. Five variables enter into a factor with relatively high factor loading. This is a group of variables about quality of network. These variables are merged into one factor, "Network". 
Table 6. Results of exploratory factor analysis the dependent variable service

KMO and Bartlett's Test

\begin{tabular}{|c|c|c|}
\hline Kaiser-Meyer-Olkin Measu & Adequacy. & 0.500 \\
\hline Bartlett's Test of Sphericity & Approx. Chi-Square & 214.628 \\
\hline & $\mathrm{df}$ & 1 \\
\hline & Sig. & 0.000 \\
\hline
\end{tabular}

\section{Total Variance Explained}

\begin{tabular}{ccccccc}
\hline Component & \multicolumn{3}{c}{ Initial Eigenvalues } & \multicolumn{3}{c}{ Extraction Sums of Squared Loadings } \\
\cline { 2 - 6 } & Total & \% of Variance & Cumulative \% & Total & \% of Variance & Cumulative \% \\
\hline 1 & 1.655 & 82.765 & 82.765 & 1.655 & 82.765 & 82.765 \\
2 & .345 & 17.235 & 100.000 & & & \\
\hline
\end{tabular}

Extraction Method: Principal Component Analysis.

Component Matrix ${ }^{\mathrm{a}}$

\begin{tabular}{cc}
\hline Code & Component \\
\cline { 2 - 2 } & \\
\hline Service1 & 1 \\
Service2 & 0.910 \\
\hline
\end{tabular}

Source: The researcher's collecting data and SPSS

Table 6 showed that two variables are entered into a factor. Factor loading of all variables is greater than 0.5 . Cumulative is $82.765 \%$ over $50 \%$. Significance of Barlett $=0.000<0.05$, so the variables correlated together on the overall. $\mathrm{KMO}=0.500$, so factor analysis is appropriate.

Table 7. Results of exploratory factor analysis the dependent variable performance

KMO and Bartlett's Test

\begin{tabular}{llc}
\hline Kaiser-Meyer-Olkin Measure of Sampling Adequacy. & 0.500 \\
Bartlett's Test of & Approx. Chi-Square & 266.810 \\
Sphericity & df & 1 \\
& Sig. & 0.000 \\
\hline
\end{tabular}

Total Variance Explained

\begin{tabular}{ccccccc}
\hline & \multicolumn{3}{c}{ Initial Eigenvalues } & \multicolumn{3}{c}{ Extraction Sums of Squared Loadings } \\
\cline { 2 - 6 } Comp. & Total & $\begin{array}{c}\text { \% of } \\
\text { Variance }\end{array}$ & Cumulative \% & Total & \% of Variance & Cumulative \% \\
\hline 1 & 1.709 & 85.433 & 85.433 & 1.709 & 85.433 & 85.433 \\
2 & 0.291 & 14.567 & 100.000 & & & \\
\hline
\end{tabular}

Component Matrix

\begin{tabular}{cc}
\hline & Component \\
\cline { 2 - 2 } Code & $\mathbf{1}$ \\
\hline Performance2: The Internet banking system will create some benefit for your company & 0.924 \\
Performance1: Using the Internet banking system will be good and benefit for consumers & 0.924 \\
\hline
\end{tabular}

Source: The researcher's collecting data and SPSS 
Table 7 showed that two variables are entered into a factor. Factor loading of all variables is greater than 0.5. Cumulative is $85.433 \%$ over $50 \%$. Significance of Barlett $=0.000<0.05$, so the variables correlated together on the overall. $\mathrm{KMO}=0.500=0.5$, so factor analysis is appropriate.

\subsection{Results of Regression Analysis of the Performances of Internet Banking}

We conducted regression analysis to determine the specific weighting of each factor to Security and Performance. Regression analysis will be performed with three independent variables: Network; Convenience; Security and the dependent variables: Service and Performance. The value of the factors used to run the regression is the standardized value of the tested variables. Regression analysis was performed with SPSS 20.0 software. Regression results are shown as follows:

\section{The first model:}

$$
\text { Service }=\beta 0+\beta_{1} \text { Network }+\beta_{2} \text { Convenience }+\beta_{3} \text { Security }
$$

Table 8 . Summary regression results of the first model

\begin{tabular}{|c|c|c|c|c|c|c|}
\hline \multicolumn{7}{|c|}{ Model Summary } \\
\hline Model & $\mathrm{R}$ & R Square & Adjusted R Square & \multicolumn{3}{|c|}{ Std. Error of the Estimate } \\
\hline 1 & $0.798^{\mathrm{a}}$ & 0.637 & 0.621 & \multicolumn{3}{|c|}{0.47883} \\
\hline \multicolumn{7}{|c|}{$\begin{array}{r}\text { a. Predictors: (Constant), Security, Network, Convenience } \\
\text { ANOVA }^{\mathbf{b}}\end{array}$} \\
\hline Model & & Sum of Squares & $\mathrm{df}$ & Mean Square & $\mathrm{F}$ & Sig. \\
\hline \multirow[t]{3}{*}{1} & Regression & 83.121 & 3 & 27.707 & 420.845 & $0.000^{\mathrm{a}}$ \\
\hline & Residual & 87.355 & 381 & 0.229 & & \\
\hline & Total & 170.477 & 384 & & & \\
\hline
\end{tabular}

a. Predictors: (Constant), Security, Network, Convenience

b. Dependent Variable: Service

\section{Coefficients $^{\mathrm{a}}$}

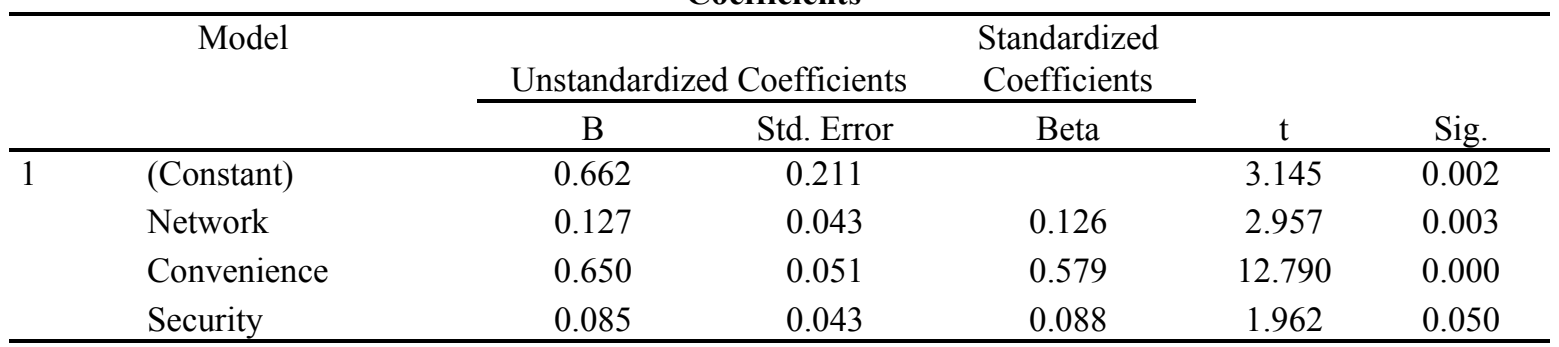

a. Dependent Variable: Service

Source: The researcher's collecting data and SPSS

Table 8 showed that the Adjusted R Square in this model is 0.621 . This showed that $62.1 \%$ variation of Security is explained by the variations of Quality of Network, Convenience of Customers and Security. Table 8 showed that the ANOVA analysis show that $\mathrm{F}=420.845$ and Sig. $=0.000$, indicating that the regression model is developed consistent with the data collected. Table 8 showed that the Sig. F change of the independent variables (Quality of Network, Convenience of Customers and Security) in the model are less than 0.05 we find the included variables are statistically significant with significance level of 5\%. Thus the independent variables in the model are related to the dependent variable. Regression results show that all three independent variables Quality of Network, Convenience of Customers and Security affect Service satisfaction of Costumers by Sig coefficients of all two variables are less than $5 \%$. Such a linear regression model is:

$$
\text { Service }=0.662+0.127 \text { Network }+0.650 \text { Convenience }+0.085 \text { Security }
$$

Table 9 showed that the factor "Convenience of Costumers" is the most influential factor to Service satisfaction of Costumers with Beta coefficient $=0.650$. Factor "Quality of Network" has beta coefficient $=0.127$ positive impact to 
Service satisfaction of Costumers. And factor "Security" has beta coefficient $=0.085$ positive impact to Service satisfaction of Costumers. Thus, the results demonstrate "Convenience of Costumers" and "Quality of Network and Security" are all crucial focus factors impact to Service satisfaction of Costumers.

The second model:

$$
\text { Performance }=\beta 0+\beta_{1} \text { Network }+\beta_{2} \text { Convenience }+\beta_{3} \text { Security }
$$

Table 9. Summary regression results of the second model

Model Summary

\begin{tabular}{lcccccc}
\hline Model & $\mathrm{R}$ & $\mathrm{R}$ Square & Adjusted R Square & \multicolumn{2}{c}{ Std. Error of the Estimate } \\
\hline 1 & $0.788^{\mathrm{a}}$ & 0.621 & 0.602 & 0.54319 & \\
\hline \multicolumn{7}{l}{ a. Predictors: (Constant), Security, Network, Convenience } \\
\multicolumn{7}{c}{ ANOVA $^{\mathbf{b}}$} \\
\hline Model & Sum of Squares & $\mathrm{df}$ & Mean Square & $\mathrm{F}$ & Sig. \\
\hline 1 & Regression & 65.847 & 3 & 21.949 & 474.390 & $.000^{\mathrm{a}}$ \\
& Residual & 112.415 & 381 & .295 & & \\
& Total & 178.262 & 384 & & & \\
\hline
\end{tabular}

a. Predictors: (Constant), Security, Network, Convenience

b. Dependent Variable: Performance

\begin{tabular}{|c|c|c|c|c|c|c|}
\hline \multicolumn{7}{|c|}{ Coefficients $^{\mathrm{a}}$} \\
\hline & \multirow[t]{3}{*}{ Model } & & & \multirow{3}{*}{$\begin{array}{c}\text { Standardized } \\
\text { Coefficients } \\
\text { Beta } \\
\end{array}$} & \multirow[b]{3}{*}{$\mathrm{t}$} & \multirow[b]{3}{*}{ Sig. } \\
\hline & & \multicolumn{2}{|c|}{ Unstandardized Coefficients } & & & \\
\hline & & B & Std. Error & & & \\
\hline \multirow[t]{4}{*}{1} & (Constant) & .951 & .239 & & 3.980 & .000 \\
\hline & Network & .345 & .049 & .333 & 7.057 & .000 \\
\hline & Convenience & .302 & .058 & .263 & 5.243 & .000 \\
\hline & Security & .151 & .049 & .153 & 3.076 & .002 \\
\hline
\end{tabular}

a. Dependent Variable: Performance

Source: The researcher's collecting data and SPSS

Table 9 showed that the Adjusted R Square in this model is 0.602 . This shows that $60.2 \%$ variation of Performance is explained by the variations of Quality of Network, Convenience of Customers and Security. Table 10 showed that the ANOVA analysis show that $\mathrm{F}=474.390$ and Sig. $=0.000$, indicating that the regression model is developed consistent with the data collected. Table 10 showed that the Sig. F change of the independent variables (Quality of Network, Convenience of Customers and Security) in the model are less than 0.05 we find the included variables are statistically significant with significance level of 5\%. Thus the independent variables in the model are related to the dependent variable. Regression results show that all three independent variables Quality of Network, Convenience of Customers and Security affect Performance by Sig coefficients of all two variables are less than $5 \%$. Such a linear regression model is:

$$
\text { Performance }=0.951+0.345 \text { Network }+0.302 \text { Convenience }+0.151 \text { Security }
$$

Table 9 showed that the Factor "Quality of Network" is the most influential factor to Performance with Beta coefficient $=0.345$. Factor "Convenience" has beta coefficient $=0.302$ positive impact to Performance. And factor "Security" has beta coefficient $=0.151$ positive impact to Performance. Thus, the results demonstrate "Quality of Network" and "Convenience and Security" are all crucial focus factors impact to Performance. 
Table 10. Summary of hypothesis testing results

\begin{tabular}{clc}
\hline Hypothesis & \multicolumn{1}{c}{ Factors } & Results \\
\hline $\mathrm{H}_{1}$ & $\begin{array}{l}\text { The Quality of Network will direct impact on satisfaction of } \\
\text { customers of Internet Banking in Vietnam }\end{array}$ & Accepted \\
\hline $\mathrm{H}_{2}$ & $\begin{array}{l}\text { Convenience of Customers will direct impact on satisfaction of } \\
\text { customers of Internet Banking in Vietnam }\end{array}$ & Accepted \\
\hline $\mathrm{H}_{3}$ & $\begin{array}{l}\text { The security will direct impact on satisfaction of costumers of } \\
\text { Internet Banking in Vietnam }\end{array}$ & Accepted \\
\hline $\mathrm{H}_{4}$ & $\begin{array}{l}\text { The satisfaction of costumers will direct influence on the } \\
\text { performance of Internet Banking in Vietnam }\end{array}$ & \\
\hline
\end{tabular}

Source: author synthesize

Table 10 showed that the above results the hypothesis is acceptable means to raise to these factors would be increase the performance of Internet Banking in Vietnam. Based on the model, the authors will calibrate the scale to suit the proposed model to adjust on the basis that the appropriate solution based on the scale is determined as follows:

\section{Model summary analysis for the performance of Internet Banking}

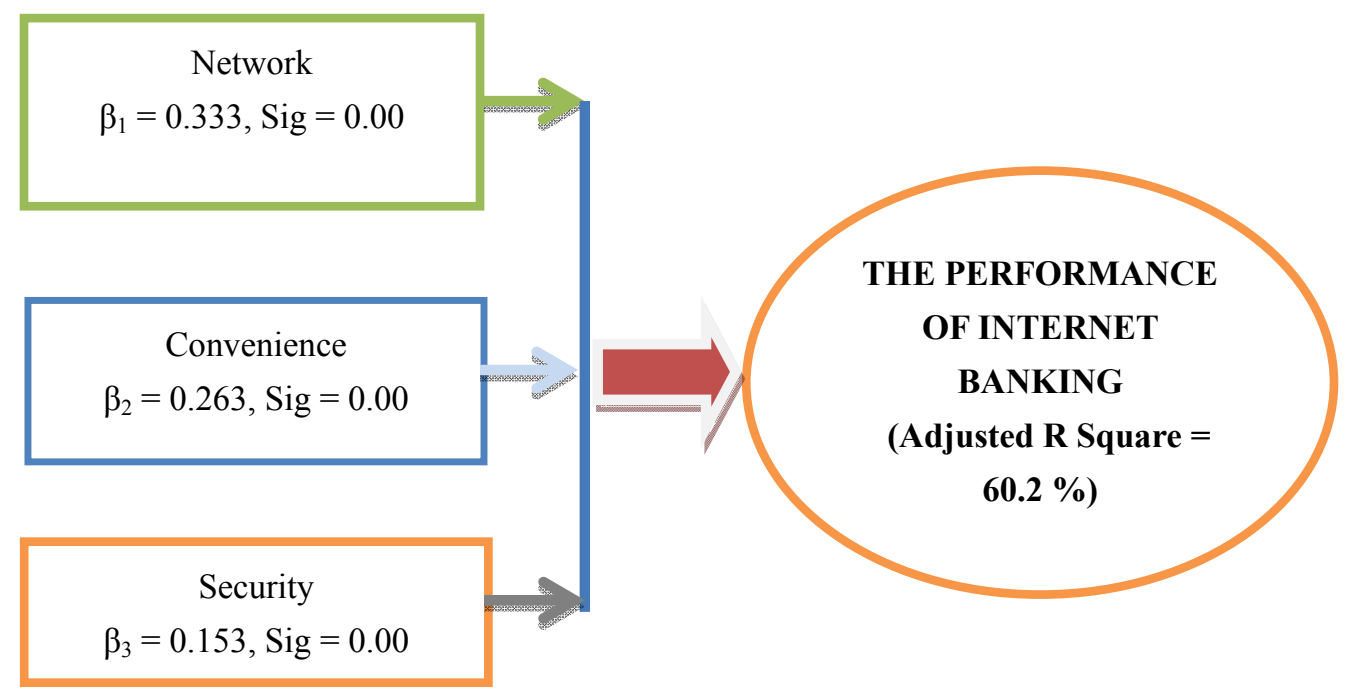

Figure 2. The Result of the Regression for the performance of Internet Banking

Figure 2 showed that the regression coefficients were positive. This means that the effects of independent variables are in the same direction to the performance of Internet Banking with signification 5\%. 

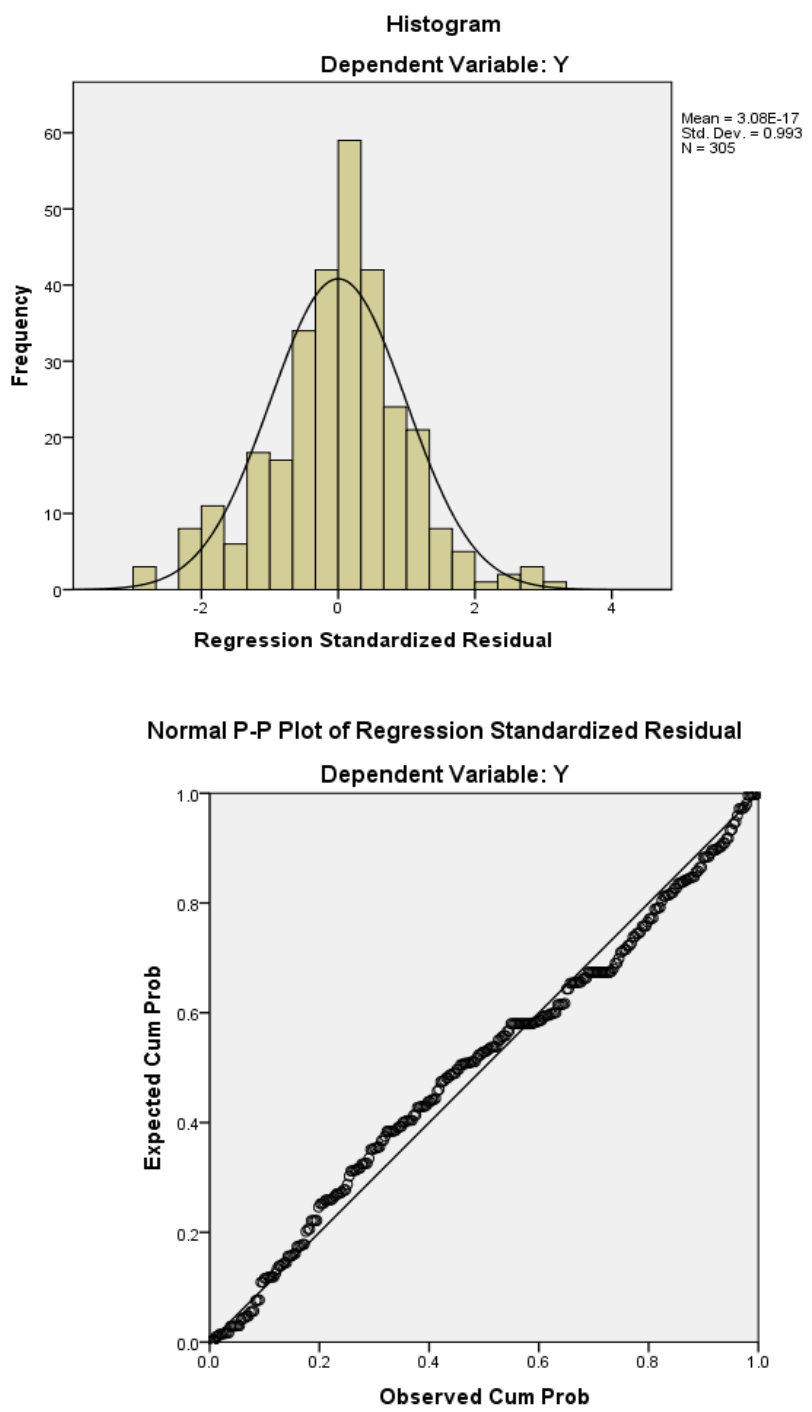

Figure 3. The result of the regression standardized residual

Figure 3 showed that the standardized residual the performance of Internet Banking was normal distribution (Standard deviation $=0.993$, nearly $=1$ ).

\section{Analysis of ANOVA for the performance of Internet Banking}

Table 11. Analysis of Variance (ANOVA) about gender

\begin{tabular}{lccccc}
\hline \multicolumn{1}{c}{ Gender } & Sum of Squares & df & Mean Square & F & Sig. \\
\hline Between Groups & 2.656 & 1 & 2.656 & 9.159 & .003 \\
Within Groups & 111.077 & 383 & .290 & & \\
Total & 113.734 & 384 & & & \\
\hline
\end{tabular}

Source: The researcher's collecting data and SPSS

The results of the table 11 revealed that Analysis of Variance (ANOVA) about Gender showed that $\mathrm{F}=9.159$ was statistically significant and Significance value was $0.03(<0.05)$. Therefore, we reject $\mathrm{H}_{0}$ and accept $\mathrm{H}_{1}$. This showed that there was different from Gender for the performance of Internet Banking with significance level of $5 \%$. 
Table 12. Analysis of Variance (ANOVA) about marriage status

\begin{tabular}{lccccc}
\hline Marriage status & Sum of Squares & $\mathrm{df}$ & Mean Square & F & Sig. \\
\hline Between Groups & .627 & 1 & .627 & 2.122 & .146 \\
Within Groups & 113.107 & 383 & .295 & & \\
Total & 113.734 & 384 & & & \\
\hline
\end{tabular}

Source: The researcher's collecting data and SPSS

The results of the table 12 showed that Analysis of Variance (ANOVA) about Marriage status showed that $\mathrm{F}=2.122$ was statistically significant and Significance value was $0.146(>0.05)$. Therefore, we reject $\mathrm{H}_{1}$ and accept $\mathrm{H}_{0}$. This showed that there was no different from Marriage status for the performance of Internet Banking with significance level of $5 \%$.

Table 13. Analysis of Variance (ANOVA): The level of using online service

\begin{tabular}{lccccc}
\hline & Sum of Squares & df & Mean Square & F & Sig. \\
\hline Between Groups & .685 & 1 & .685 & 2.320 & .129 \\
Within Groups & 113.049 & 383 & .295 & & \\
Total & 113.734 & 384 & & & \\
\hline
\end{tabular}

Source: The researcher's collecting data and SPSS

The results of the table 13 revealed that Analysis of Variance (ANOVA) about the level of using online service showed that $\mathrm{F}=2.320$ was statistically significant and Significance value was $0.129(>0.05)$. Therefore, we reject $\mathrm{H}_{1}$ and accept $\mathrm{H}_{0}$. This showed that there was no different from the level of using online service for the performance of Internet Banking with significance level of $5 \%$.

Table 14. Analysis of Variance (ANOVA) about experiences

\begin{tabular}{lccccc}
\hline & Sum of Squares & df & Mean Square & F & Sig. \\
Between Groups & 10.506 & 3 & 3.502 & 12.926 & .000 \\
\hline Within Groups & 103.227 & 381 & .271 & & \\
Total & 113.734 & 384 & & & \\
\hline
\end{tabular}

Source: The researcher's collecting data and SPSS

The results of the table 14 showed that Analysis of Variance (ANOVA) about Experienced showed that $\mathrm{F}=12.926$ was statistically significant and Significance value was $0.000(<0.05)$. Therefore, we reject $\mathrm{H}_{0}$ and accept $\mathrm{H}_{1}$. This showed that there was different from Experience in Internet Banking for the performance of Internet Banking with significance level of $5 \%$.

Table 15. Analysis of Variance (ANOVA) about the salary

\begin{tabular}{lccccc}
\hline & Sum of Squares & df & Mean Square & F & Sig. \\
\hline Between Groups & .509 & 3 & .170 & .571 & .634 \\
Within Groups & 113.225 & 381 & .297 & & \\
Total & 113.734 & 384 & & & \\
\hline
\end{tabular}

Source: The researcher's collecting data and SPSS 
The results of the table 15 showed that Analysis of Variance (ANOVA) about the Salary showed that $\mathrm{F}=1.571$ was statistically significant and Significance value was $0.634(>0.05)$. Therefore, we reject $\mathrm{H}_{1}$ and accept $\mathrm{H}_{0}$. This showed that there was no different from the Salary for the performance of Internet Banking with significance level of $5 \%$.

Table 16. Analysis of Variance (ANOVA) about the age

\begin{tabular}{lccccc}
\hline & Sum of Squares & df & Mean Square & F & Sig. \\
\hline Between Groups & 5.097 & 3 & 1.699 & 5.959 & .001 \\
Within Groups & 108.636 & 381 & .285 & & \\
Total & 113.734 & 384 & & & \\
\hline
\end{tabular}

Source: The researcher's collecting data and SPSS

The results of the table 16 revealed that Analysis of Variance (ANOVA) about the Age showed that $\mathrm{F}=5.959$ was statistically significant and Significance value was $0.001(<0.05)$. Therefore, we reject $\mathrm{H}_{0}$ and accept $\mathrm{H}_{1}$. This showed that there was different from the Age for the performance of Internet Banking with significance level of $5 \%$.

\section{Conclusions}

The research results showed that there were 410 customers interviewed and answered about 18 questions but 385 customers processed. The researcher had analyzed KMO test, the result of KMO analysis used for multiple regression analysis.

The regression analysis result showed that there were three factors, which included of factors following: Network; Convenience; and Security affecting the performance of Internet Banking with significance level $5 \%$. In addition, the research result processed from SPSS 20.0 version. The parameters of the model estimated by Least - Squares Method tested for the model assumption with 5\% significance level. At the same time, the result was also a scientific evidence and important for researchers, and policy makers who apply them for the improvement of the performance of Internet Banking in the future. The multiple regression coefficients were standardized by 3 factors: Network, Convenience and Security to ensure meaningful statistical significance level Sig are small than 0.05 . However, in practice these factors are affecting the performance of Internet Banking.

Internet banking service is really a kind of modern payment with many advantages. This service brings many benefits to both banks and consumers. Furthermore, in the era of information technology is developing rapidly developing internet banking service will play an important role in the development process as well as helpful to the development of banking services. Internet banking services opens up many prospects to improve the efficiency of payment services as well as improving the quality of banking services to help increase the competitiveness of the banking sector in the international arena. Besides internet banking also caused many difficulties and challenges for the banking industry, consumers as well as the management which requires each bank to take measures and steps in line with their goals and objectives of the whole society.

\section{References}

Amin, H. (2007). Internet banking adoption among young intellectuals. Journal of Internet Banking and Commerce.

Balogun, O. J. (2013). An Investigative Study on Factors Influencing the Customer Satisfaction with E-Banking in Nigeria. International Journal of Academic Research in Economics and Management Sciences.

Beh Yin Yee, \& T. M. Faziharudean. (2010). Factors Affecting Customer Loyalty of Using Internet Banking in Malaysia. Journal of Electronic Banking Systems.

Berry, L. L., Parasuraman, A., \& Zeithaml, V. A. (1994). Improved service quality in America: Lessons learned. Academy of Management Executive.

Chaisomphol Chaoprasert. (2004). Service Quality Improvement in Thai Retail Banking and its Management Implications. Journal of Business and Policy Research.

Chang, P. V. (2004). The validity of an extended technology acceptance model (TAM) for predicting intranet/portal usage. University of North Carolina, Chapel Hill, NC.

Dillman, D. A. (2000). Mail and Internet Surveys. The Tailored Design Method, New York, Wiley. 
Dochartaigh, N. O. (2002). The Internet Research Handbook: A Practical Guide for customers and Researchers in The Social Sciences. London, Sage.

Eriksson, K., Kerem, K., \& Nilsson, D. (2005). Customer acceptance of internet banking in Estonia. International Journal of Bank Marketing.

Fink, A. (2003). How to Ask Survey Questions. Thousand Oaks, CA, Sage.

Freedman, D. A. (2005). Statistical Models: Theory and Practice. Cambridge University Press.

Freedman, P. (1960). The Principles of Scientific Research. New York: Pergamon Press.

Grabner-Krauter, S., \& Faullant, R. (2008). Consumer acceptance of internet banking: the influence of internet trust. International Journal of Bank Marketing.

Grönroos, C. (1990). Service Management and Marketing. Lexington Books, Lexington, MA.

Gurau, C. (2002). Online banking in transition economies: the implementation and development of online banking systems in Romania. International Journal of Bank Marketing.

Kumar, R. (2005). Research Methodology: A Step-by-step Guide for Beginners. Melbourne, Australia: Longman.

Muhammad Hamid. (2012). Factors Affecting the Brand Recognition: An Exploratory Study. Global Journal of Management and Business Research.

Özlem Altun. (2012). Factors Affecting the Use of Internet Banking; the Case of Northern Cyprus. International Journal of Academic Research in Business and Social Sciences.

Parasuraman, A., Berry, L. L., \& Zeithaml, V. A. (1991). Under-standing customer expectations of service. Sloan Management Review, Spring.

Parasuraman, A., Zeithaml, V. A, \& Berry, L. (1988). SERVQUAL: a multiple - item scale for measuring consumer perceptions of service quality. J. Retail.

Pavla Vodová. (2011). Determinants of Commercial Banks' Liquidity in the Czech Republic. Journal of Research in International Business and Management.

Pirow. (1990). How to do Business Research. Juta Publishers.

Rothaermel, F. T., \& Sugiyamanb, S. (2001). Virtual Internet Communities and Commercial Success: Individual and Community-Level Theory Grounded in the Atypical Case of Timezone.com. London: Sage Publications.

Sallehuddin Mohd Nor. (2011). Factors Affecting Brand Loyalty: An Empirical Study in Malaysia. Australian Journal of Basic and Applied Sciences.

Saunders, M., Lewis, P., \& Thornhill, A. (2007). Research Methods for Business Students. United Kingdom: Prentice Hall.

Singh Harpreet, \& Kaur Harneet. (2008). Concepts and practices of research methodology. New Delhi: Kalyani publisher.

Stephen Pambiin Jalulah. (2011). Evaluation of customer satisfaction with Internet banking service quality in the banking industry in Ghana. Journal of Business and Policy Research.

Zeithaml, V. A., \& Bitner, M. J. (1996). Services Marketing. McGraw-Hill, New York.

Zeithaml, V. A., \& Parasuraman, A. (2004). Service Quality, MSI Relevant Knowledge Series. Cambridge, MA: Marketing Sience Institute.

Zikmund, W. G. (2003). Exploring Marketing Research. Cincinnati, Ohio: Thomson/ South-Western. 